A major purpose or tne I ecrirical Information Center is to provide the broadest dissemination possible of information contained in DOE's Research and Development Reports to busine industry, the academic community, and federal, state and local governments.

Although a smail portion of this report is not reproducible, it is being made available to expedite the availability of information on the research discussed herein. 
LA-UR -83-2151

$$
\text { C.ONF- } 83069=-1
$$

LA-UR--83-2151

DE83 015220

TITLE SUBHARMONIC BUNCHER FOR THE LUS ALAMOS FREE-ELECTRON LASER

OSCILLATOR EXPERIMENT

AUTHORISI JOHN J. FRASER

NOTICE

PORTIOHS OF THIS AEPOAT ARE ILLEGIBLE.

II has been roproduced from tho best uvallable copy to pormit the breadest. possible avallability. is

SUBMITTED TO THE SOCIETY OF PHOTO-OPTICAL INSTRUMENTATION ENGINEERS

Bellingham, WASH

DISCLAIMER

This repurt was prepared as an account of work aponeored by an agency of the Unitod Statea Government. Neither the United Siates Government nor any asency thereof, nor any of their employeus, maker any warranty, expreas of implied, or asumes any lejal liability or responsibility for the accuracy. completeneas, or usefulnew of any information, epparntur, product, or process disclosed, of represents that its use would not infringe privalely uwned rights. Refarence heroin to any apesilic commerctal product, procese, or enrice hy irade seme, trademerk. manufacturer, or etherwite does nol necesarily constilute or imply th endorsement, recominendaliun, or favoring by the Uaited Situtes (toverninent of uny anency thereof. The viow and opinisnr of suthors expresed herein do not neccessurily stute or reflect those of the Uniled Situtex (iovernment or any agency thereof.

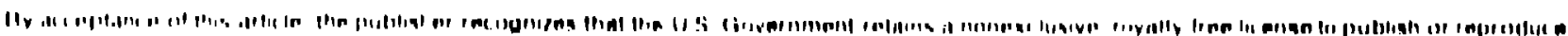

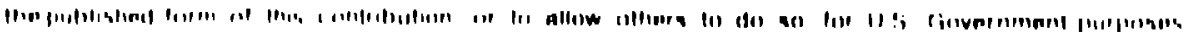

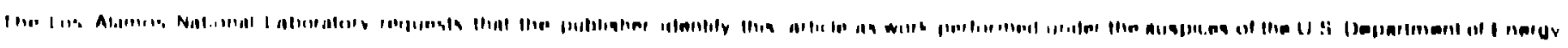

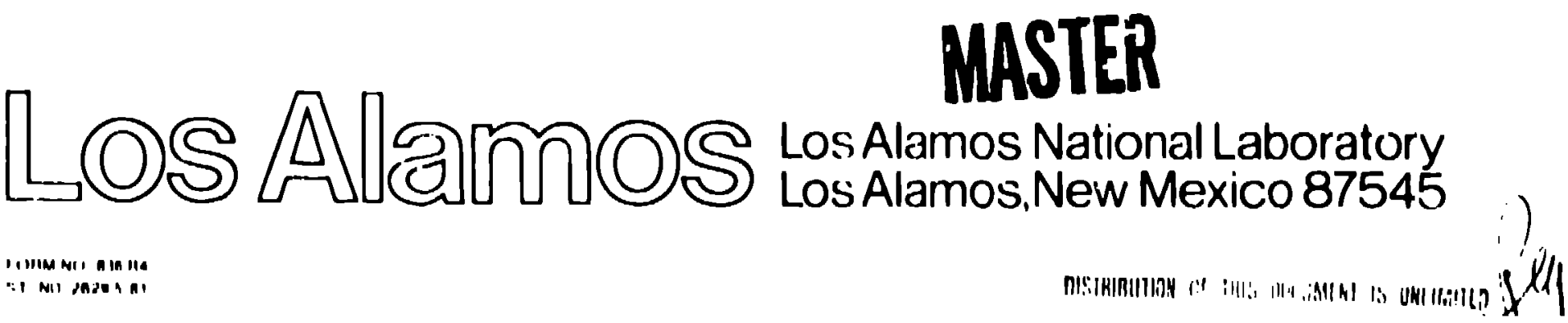




\author{
Subharmonic Buncher for the Los Alamos \\ Free-Electron Laser Oscillator Experiment * \\ J. S. Fraser \\ Los Alamos National Laboratory \\ AT-7, MS H825, Los Alamos, New Mexico 87545
}

\begin{abstract}
A high efficiency free-electron laser oscillator experiment is being coristructed at Los, Alamos National Laboratory. A buncher system has been designed to deliver 30-ps, 5-nC electron bunches to a 20-MeV standing-wave linac at the 60th subharmonic of the 1300-MHz accelerator frequency. The first 108.3-MHz buncher cavity accepts a 5-ns, 5-A peak current pulse from a triode gun. Following a 1210-cm drift space, a second 108.3-Mliz cavity is used, primarily to enhance the bunching of the tralling half of the bunch. A 1300-MHz cavity witn $20-\mathrm{cm}$ drift spaces at the each end completes the beamline components. The bunching process continues into the linac's first three accelerating cells. Tro thin irori-shielded lenses and several large-diameter solenoids provide axial inạ̧netic fields for radial focusing.
\end{abstract}

\title{
Introduction
}

The experimental conditions of the frec electron laser osciliator experiment at Los $\mathrm{Alanos}$ require a single optical bunch in the \%-m-long resonator. Therefore, the repetition rate of the electron beali bunches must be -30 ps long and contaln at loast 3 nC per bunch to the linac.

A litton triode gun with a grid pulser and a postaccelerator was designed to delfver a peak current of over $5 \mathrm{~A}$ at $80 \mathrm{keV}$, with a base width of 5 ns. The computed normalized transverse emlttance ${ }^{1}$ is - $25 \pi$ mine mrad. Tapered of III: coppeer npertures are provided to spattaily filter the: gun emittance, if necessidry, to achiove the requtred entleance of in muluriad at Po MeV in the wlygler.

$\star$

Worke performind for Defense Advallend Research Projects Ayency under the ausplecs of US Bepartiment of Cneryy. 


\section{Choice of Subharmonic Frequency}

The length $\ell$ of the optical cavity is constrained for various reasons to lie between 4 and $8 \mathrm{~m}$ and is related to the gun-pulse frequency $f_{\text {gun }}$ by $\ell=150 \mathrm{f}_{\text {gun }}^{-1}$, where $\ell$ is in meters and $f$ is in megahertz. The gun-pulse width must. be shorter than a half-period of the first subharmonic buncher-cavity field; therefore, $f_{\text {shb }}^{-1}>2$ times the gunpulse width. Finally, the gun-pulse frequency and the subharmonic buncher frequency must be harmonically related to the linac irequency, $1300 \mathrm{MHz}$, and to each other. Hence, $f_{\text {shb }}=1300 / \mathrm{n}, f_{\text {gun }}=1300 / \mathrm{m}$, and $m / n=k$, where $k, m$, and $n$ are integers. A lower limit on $f_{\text {shb }}$ is imposed to minimize the size of the buncher cavities, which are located within the central boreholes of several solenoid magnets.

The chosen parameters are $n=12, m=60$, and $\%=6.92 \mathrm{~m}$. Fur $n<12$, the $r f$ period is too short; for $n<13$, the cavities are too large; and for $m>60$, the o;tical cavity is too large. Therefore, $f_{\text {gun }}=21.67 \mathrm{MHz}$ and $\mathrm{f}_{\text {shb }} \cdot 108.33 \mathrm{MHz}$.

\section{Design Calculations}

if one-dimensional ring $c$ de? was used as a guide in selecting the number and location of the tuncher cavittes and to select field amplitudes and phases in the cavities. This code is the most recent in a long line of computer simulations derived from the large.signal theory of traveling-wave tube amplifiers. ${ }^{3}$ The ring radius is assumed to remain constant, whlle the current's effectlve value tricreases as the bunching procends.

As a complementary approach, inteyration of the Pierce paraxial envelope equation was used to determine the axlal nagnetic field required lo maintain brillouin flow or constant cqullibrium beam rautus. The plerce equation fynores beam emittance but this is acceptable for the 
pre $t$ case in which space charge forces dominate the beam behaviour throw out the injector. 5

The :xial magnetic fieid produced by a trial set of collinear solenoids was calculated for use in the paraxial envelope code. The beam current's effective value was assumed to increase linearly from $5 \mathrm{~A}$ at the first buncher to $100 \mathrm{~A}$ at the elld of the bunching region.

The chosen design, bascd on the foregoing calculations, consists of two subharmonic-frequency buncher cavities and one buncher cavity at the linac frequency. The ring-model calculation shows clearly that under the given input conditions, the initial bunching must be gentle, with a long drift space. A second subharmonic burcher cavity is required to correct a nonlinear bunching that is an unavoidable relativistic effect. Equal and opposite energy changes imposed in the two halves of the sinusoidal buncher field result in different values of fractional velocity change, hence different bunching. The second buncher is phased to enhance the bunching of the trailing half of the bunch. Finally, the third cavity is required to compress the bunch sufficiently so as to minimize the energy spread in the high field gradients of the first three accelerator cells, where further bunching occurs.

The bunching voltages, phases, frequencies, and drift distance: following each buncher gap are given in Table 1.

The charge and energy distributions after passing through the third graded- $B$ linac cell are shown in Fig. 1. The total charge injected into the first subharmonic bunhcer was $20 \mathrm{nC}$. In Fig. 1, the total charge in the central peak, 34 ps wide, is $13 \mathrm{nC}$. In the emergy spectrum, the peak, which is $160 \mathrm{knV}$ wide, contains $9 \mathrm{nC}$.

The results of integrating the paraxial envelope rquation with the chosen solenoid parameters are shown in fig. ?. Brillouin flow was not. achioved with the assuined conditions, hut the scalloping is small onough to allow the bean to be tranported within the avallable apertures. 
TABLE I

BUNCHER VOLTAGES, PHASES, FREQUENCIES, AND DRIFT DISTANCES

\begin{tabular}{|c|c|c|c|c|}
\hline $\begin{array}{l}\text { Cavity } \\
\text { No. } \\
\end{array}$ & $\begin{array}{l}\text { Frequency } \\
(\mathrm{MHz})\end{array}$ & $\begin{array}{l}\text { Peak } \\
\text { Voltage } \\
\text { (kV) } \\
\end{array}$ & $\begin{array}{l}\text { Phase (degrees } \\
\text { with respect to } \\
\text { reference ring) }\end{array}$ & $\begin{array}{r}\text { Drift } \\
(\mathrm{cm})\end{array}$ \\
\hline $\begin{array}{l}? \\
2 \\
3\end{array}$ & $\begin{array}{l}108.33 \\
108.33 \\
1300\end{array}$ & $\begin{array}{l}30 \\
18 \\
20\end{array}$ & $\begin{array}{r}0 \\
-30 \\
-10\end{array}$ & $\begin{array}{r}120 \\
20 \\
20\end{array}$ \\
\hline
\end{tabular}

\section{Buncher Cavity Design.}

The three buncher cavities are of the coaxial resonator type. In the 108.33-MHz cavities, the over-all dimensions were recuced by $\mathrm{placing}$ disks on the ends of the inner members of the coaxial structure to provide capacitive loading. Details of the design were established with the aid of the SUPERFISH code. The measured Os were 7900 and 8400 for the $\mathrm{i08.33-}$ and 1300-MHz cavities, respectiveiy. The computed power dissipations to achieve the required peak voltages given in Table I are 1100,400 and 400 watts respectively.

The cavities are provided with tuning plungers mounted on micrometer actuators with bellows vacuum seals. The runiny $r$ alges available are 0.7 and $0.6 \%$ for tne 108.33- and 1300-MHz cavities, respectively. Each buncher cavity is provided with a water-cooling coil to stabilize the c.avity temperature.

\section{The Injector Arsenibly}

An elevation view of the complete injector assembly is shown in Fig. 3. The licam from the electron qun first passes through two thin lenses of the electromaqnet type. Stcering colls and a pumping channel are located between the inin lenses.

As the heam appronithes the first subharinonic huncher cavity, it enters a ramped axtal magnette fleld (Fig. ?). 
A second set of steering coils, a valve, and a retractable fluorescent screen are located between the two subharmonic-frequency cavities. Three broad-band wall-current monitors of the type used in the injector for the proposed SLAC Linear Collider are located in the injector beam line.

A graded set of three beam-limiting apertures is provided in the space between the two thin lenses. The apertures are tapered with a $10^{\circ}$ half-angle in a 5-cm-thick block of OFHC copper. Tapered apertures located near dispenser cathodes have been shown ${ }^{6}$ to eliminate poisoning of the cathodes caused by metal atoms sputtered upon impact of negative oxygen ions enitted from the cathode. ${ }^{7}$ The aperture diameters are 4 , 6 , and $8 \mathrm{~mm}$; a fourth position of the aperture frame presents no obstruction to the beam.

\section{Cavity excitation by the beam}

A bunched beam will radiate energy into a cavity as it passes through. In an accelerating cavity, the energy acquired from the buich will normally be inuch smaller than the energy stored in the cavity from the $r f$ generator. In a buncher cavity, however, the stored energy is relatively small. Consequently, the excitation of a buncher cavity by a pre-bunched beam cannot be igılored. Furthermore, when a train of beain bunches passes through the cavity at a repetition frequency which is a sibharincnic of the cavity iesunant frequency, the stored energy accumu?ates up to an cquilibrlum level governed by the bunch charge, the bunch repetition rate and the loaded $\eta$ value of the cavity.

The beam-induced voltage in the buncher gap wtll be $180^{\circ}$ out of phase with the bunch phase. The net buncher gap voltage will usually be required to reach its peak vaiue $90^{\circ}$ from the bunch phase hence the: beam will induce a phase shift as well as an amplltude change in the net cavity voltage. For a train of $5 \mathrm{nc}$ bunches at a repetition rate of 21.67 Mliz In a 108.3 Mliz cavity with a loaded 0 of 4000, the equilibrium beall-triduced voltage is approxtmately $34 \mathrm{kV}$. Since the net cavity vollage (in uncher number onc) is reputred to be $30 \mathrm{kV}$, the $r f$ generator voltage must be varied by a factor of $1 . b$ and its phase shifted by $19^{\circ}$ from the zero bean to full beam condition. 
Figure 4 shows the $r f$ envelope in buncher number one. The initial rise is the natural filling of the cavity. The dip in the middle of the envelope is due to the resonant build-up of the beam-induced voltage, the relative phases of the $r f$ generator and beam being such as to result in a net decrease of the cavity voltage. Figure 5 shows the result on the cavity voltage of activating the phase and amplitude control loops. The initial filling of the cavity is now much more rapid and only small transients remain at the beginning and end of the beam pulse train.

\section{Bunching Measurements}

The initial tuning of the triple buncher system was done with the aid of broadband wall current monitors. These are located $12 \mathrm{~cm}$ upstream from the first buncher, between the first and second bunchers and $7 \mathrm{~cm}$ downstream from the third. The monitor sianals were observed through 50 m of corrugated-jacket, foam-dielectric cable on a Tektronix 7104 oscilloscope. Figure 6 shows a typical pulse at the third wall-current monitor with the three bunchers op-ating. The minimum pulse width observed, about 300 ps FWHM, was undoubtedly limited hy the system response. The bunching factor over the gun pulse width of 4 ns FWHM is in excess of 13 and bunch width is simall enough to match the phase acceptance of the linac (equivalent to $350 \mathrm{ps}$ ). Further measurements on the huncher performance await the installation of longitudinal and transverse emittance diagnostics in the linac output beam line.

\section{Acknowledgments}

I am indebled to A. D. Yeremian of the Boeing Aerospace Company, Seattle, Washington, for suggesting use of the paraxial envelope equation for designing the axial magnetic field and to $R$. W. Warren for the measurements of buncher perfornance. 


\section{References}

1. R. W. True, "Design Review, Free Electron Laser L-5657 Guns and Postaccelerator Design Study," Littori Industries, March 19, 1982.

2. M. B. James and R. H. Miller, "A High Current Injector for the Proposed SLAC Linear Collider," IEEE Trane. Nucl. Sci. 28, No. 3, P. 3461 (1981).

3. P. K. Tien, L. R. Walker, and V. M. Wolontis, "A Large Signal Theory of Travelling-Wave Amplifiers," Proc. IRE, 43, p. 260 (1955).

4. J. R. Pierce, Theory and Design of Electron Beams, van Nostrand, 1949.

5. A. A. Garren, "Thin Lens Optics with Space Charge," University of California Radiation Laboratory report UCRL-19313 (1969).

6. J. S. Fraser, J. Mckeown, G. E. McMichael, and W. T. Diamond, "Operation of the Graded- $\beta$ Electron Test Accelerator," Pros. 1976 Proton Linear Accel. Conf., Chalk River Nuclear Laboratory report AECL-5677, p. 166 (1977).

7. N. A. Surplice, "Emission of Negative Ions of Oxygen from Dispenser Cáthodes, "Brit. J. Appl. Phys. 12, pp. 214, 220 (1961). 


\section{Figure Captions}

Fig. I Linac input phase and energy distribution from ine ring-model calculation.

Fig. 2. Beam radius, $R$, from the integration of the Pierce paraxial envelre equation. The axial magnetic field, $B_{7}$, is produced by th. set of lenses and solenoids indicated at the top of the figure. The current, I, is assumed. The circles are equilibrium radii from Ref. 5. Buncher bea pipe and linac apertures are indicated.

Fig. 3. The injector assembly for the Los Alamos free electron laser oscillator experiment.

Fig. 4. RF envelope in buncher number one showing the resonant buildup of the beam-induced field starting $100 \mu \mathrm{s}$ from the start of the sweep. Scale: $50 \mu \mathrm{s} / d i v$.

Fig. 5. RF envelope as in Fig. 4 but with phase and amplitude control loops operating.

Fig. 6. Bunched beam as observed at a wall-current monitor after the third buncher. Scale: 1 ns/div. 

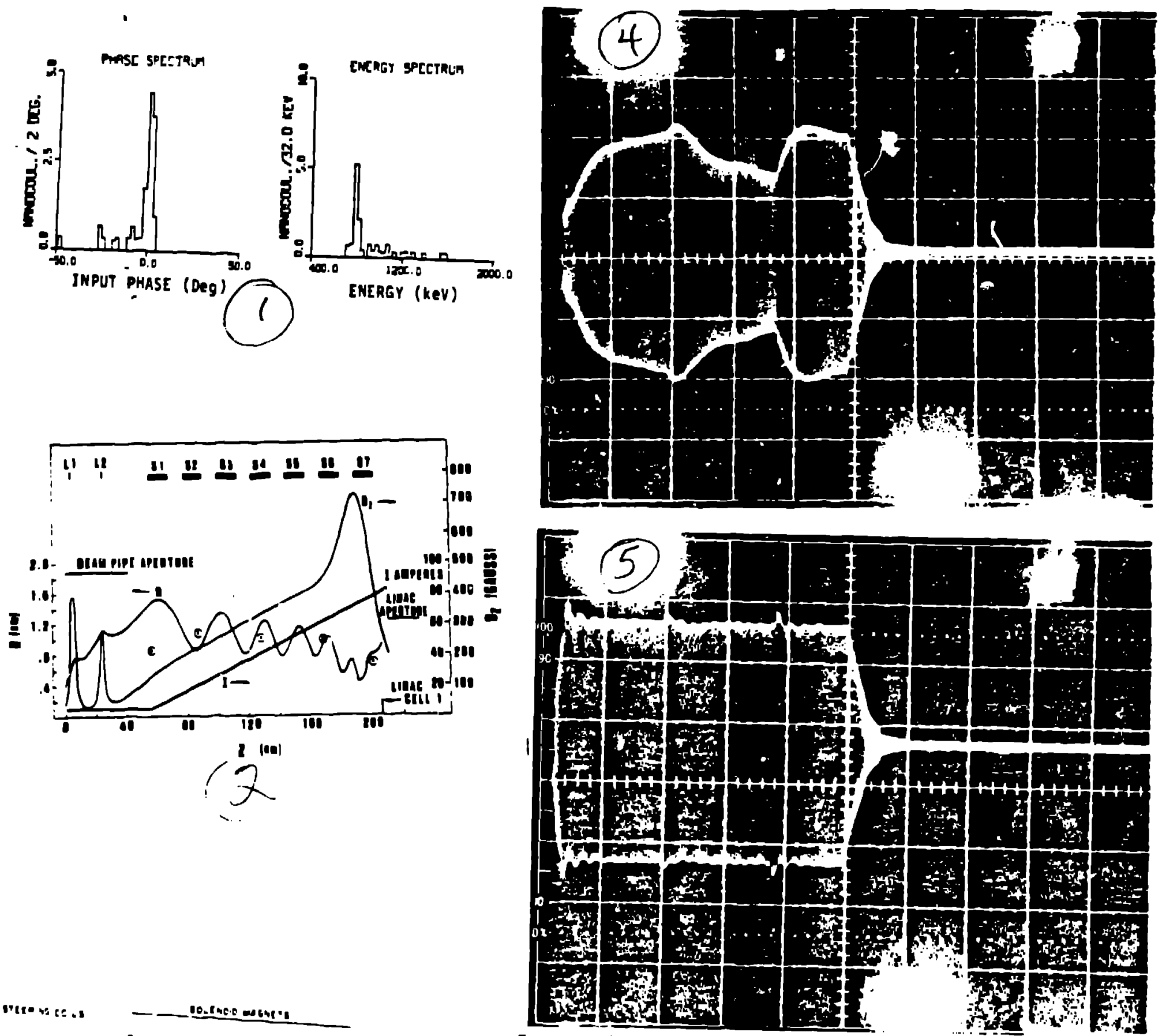

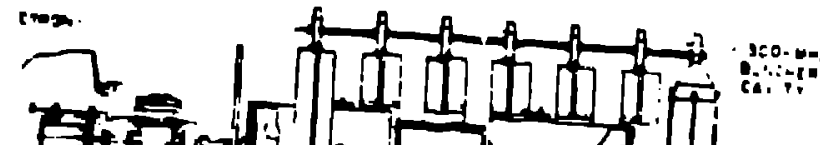

Do.ringe menters

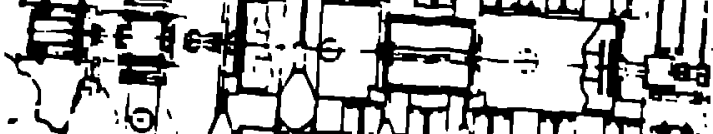

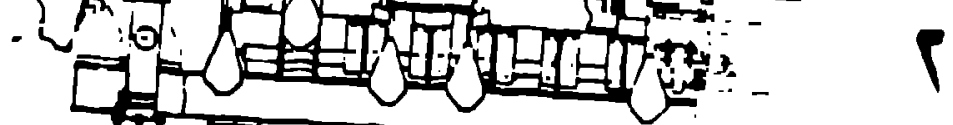

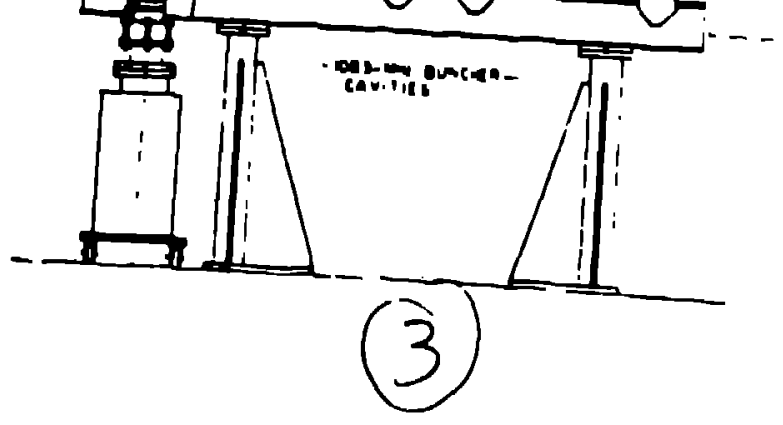

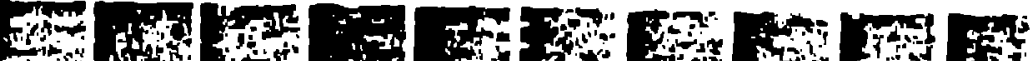

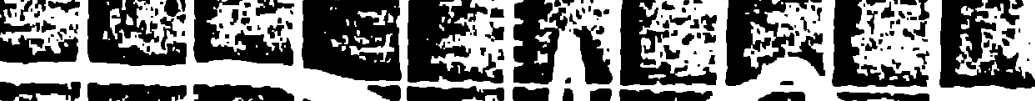

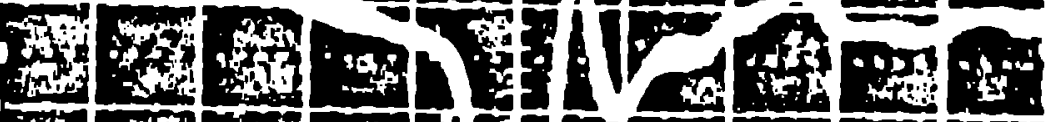
44 क

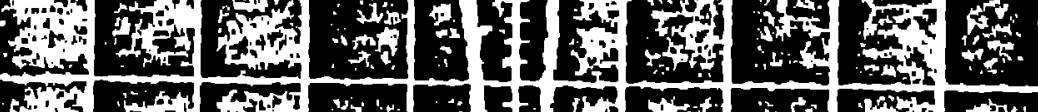

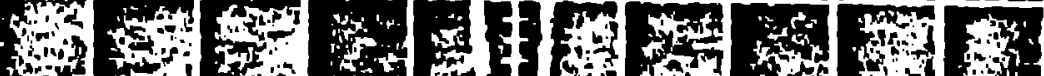

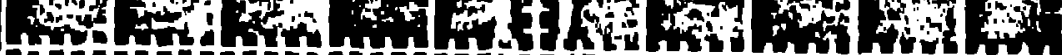

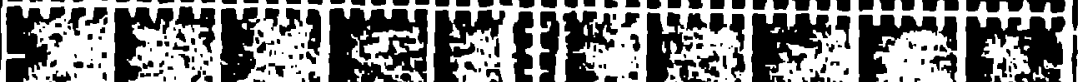

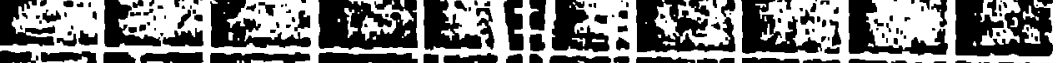

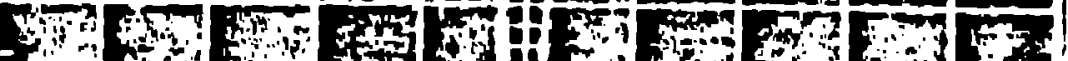

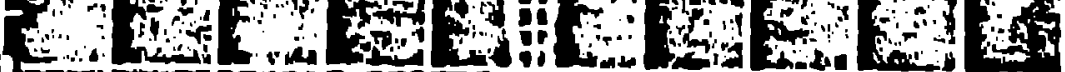

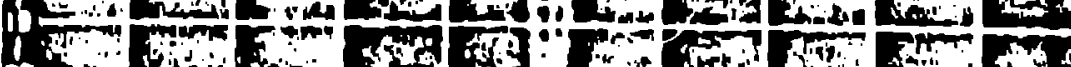

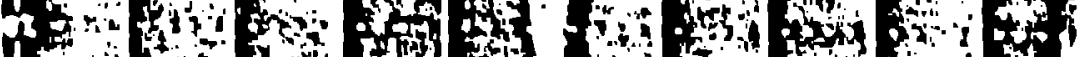

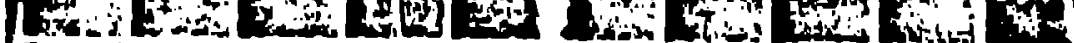

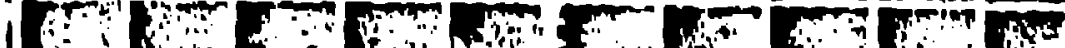

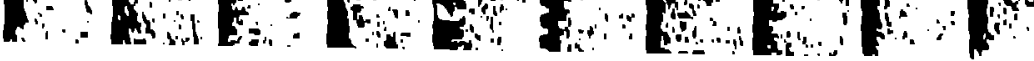

